\title{
Background to the University of Queensland Archaeological Services Unit's Lang Park Salvage Excavations: History, Significance Assessment and Methods
}

\author{
Kevin Rains ${ }^{1}$ and Jonathan Prangnell ${ }^{2}$ \\ School of Social Science, University of Queensland, Brisbane, Queensland, 4072, Australia \\ University of Queensland Archaeological Services Unit, School of Social Science, University of Queensland, \\ Brisbane, Queensland, 4072, Australia
}

\begin{abstract}
Brisbane's major football venue, Lang Park, is undergoing a \$280 million redevelopment. As part of this project the University of Queensland Archaeological Services Unit (UQASU) developed a cultural heritage management plan for the site. UQASU identified that the Lang Park site once housed a number of historic cemeteries, dating from the 1840s, and an early brick drain. These were assessed to be of high cultural heritage significance, and in 2000 UQASU formulated policies and strategies for their management. In 2001, UQASU began the salvage of those parts of the culturally significant elements that were to be deleteriously affected by earthworks and building activity. To date 397 burials have been exhumed.
\end{abstract}

\section{Introduction}

In November 1999 the Queensland Government announced a major redevelopment of the Lang Park football ground to provide Brisbane with a purpose-built rectangular stadium comparable to the Millennium Stadium in Wales. The Lang Park redevelopment site is situated in Milton, an inner western suburb of Brisbane, some $1.6 \mathrm{~km}$ from the city centre. It covers 7.4 ha bounded by Caxton, Hale, Chippendall and Castlemaine streets (Figure 1).

The Department of Communication and Information, Local Government, Planning and Sport formed a Stadium Development Group to oversee planning for the project (HOK Sport and PDT Architects 2001:4). From December 2000 to May 2001, the University of Queensland Archaeological Services Unit (UQASU) was contracted by Sinclair Knight Merz Pty Ltd and the Stadium Development Group to assess the potential subsurface deposits at the Lang Park football ground and make recommendations for their management during the various phases of redevelopment. The results of this assessment were submitted in a report that dealt specifically with nonIndigenous heritage (Prangnell and Rains 2001). Aboriginal heritage assessment was conducted separately by the Turrbal Association Inc. (2001) but the results were later included in a combined Turrbal Association Inc. and UQASU report entitled Summary Cultural Heritage Management Plan for the Proposed Lang Park Redevelopment (2001). Since the completion of UQASU's cultural heritage study, work on the redevelopment has commenced, with UQASU being retained to undertake monitoring, sampling, salvage and analysis of recovered materials.

In this paper we present the background to the development of the cultural heritage management plans for the Lang Park redevelopment. This includes the documentary and physical evidence, the establishment of the sequence of landscape changes that occurred on the site, the assessment of the heritage significance of the place and its components and the development of policies and strategies for the management of the cultural heritage values. We also outline the methods employed by UQASU in the initial stages of the salvage operation and detail preliminary results.

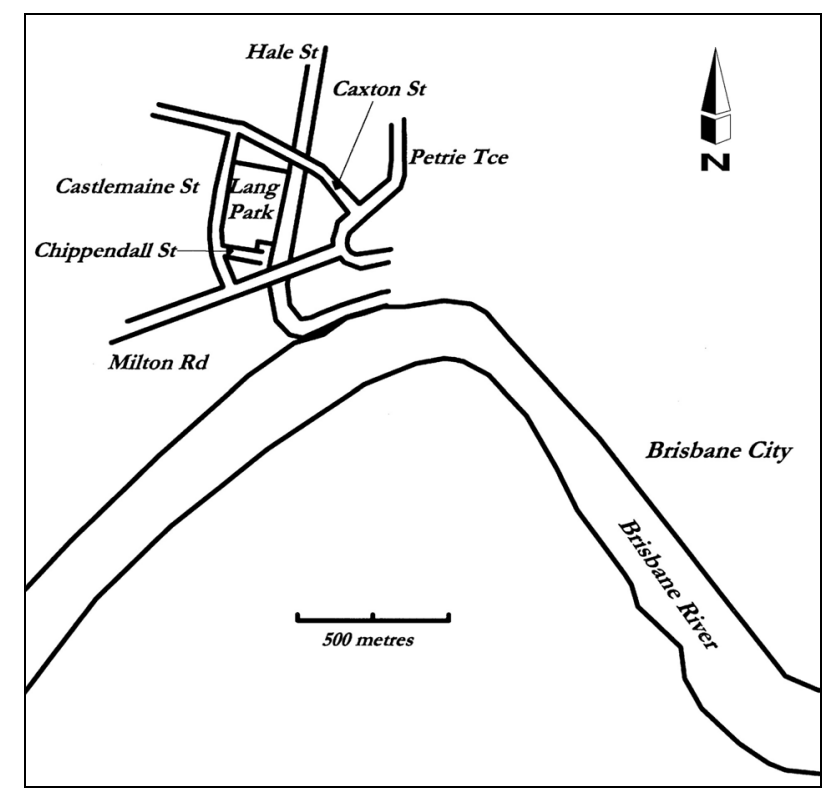

Figure 1. Location of Lang Park.

\section{Lang Park: A History}

During the early years of European expansion in Queensland, the Lang Park site contained a number of cemeteries collectively known as the Old Paddington/Milton Cemeteries, or North Brisbane Burial Grounds. The site was surveyed by September 1843 and was the first cemetery to serve the newly established settlements of North and South Brisbane when free settlement was proclaimed in 1842. It remained the principal place of interment for a period of 34 years (Fisher 1994:35-36).

The North Brisbane Burial Grounds were situated within a swampy drainage basin on the western boundary of Brisbane Town, that later become the suburbs of Paddington and Milton (Fisher 1994:36; The Telegraph 11 October 1962:25). Following cemetery design current at the time, the site was laid out as a formal urban burial ground based on the principle of denominational segregation (Fisher 1994:38) (Figures 2-3). Seven separate areas were initially set aside; six held in trust by various religious denominations and one unconsecrated section for 


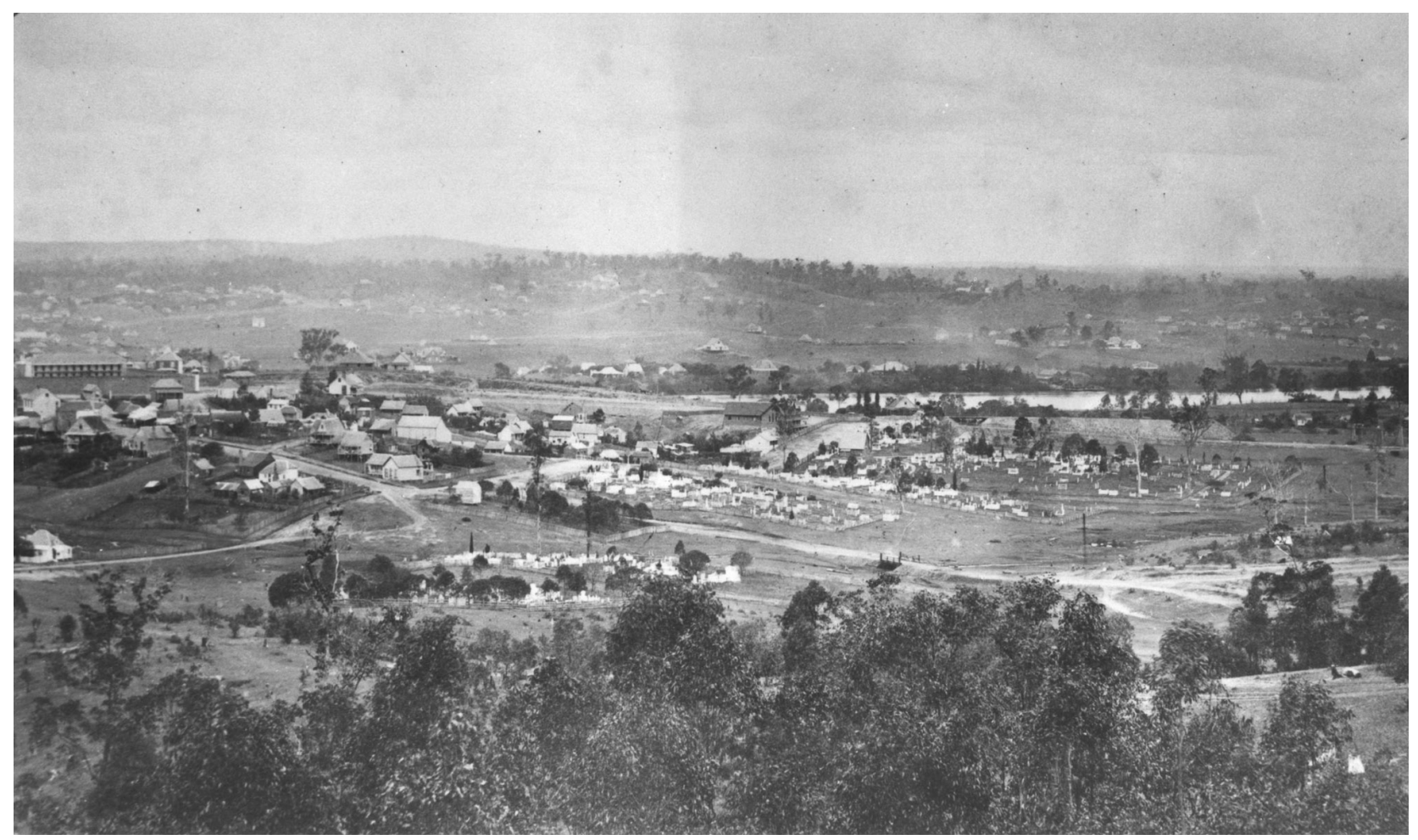

Figure 2. 1870 view of North Brisbane Burial Grounds (JOL neg. 3493).

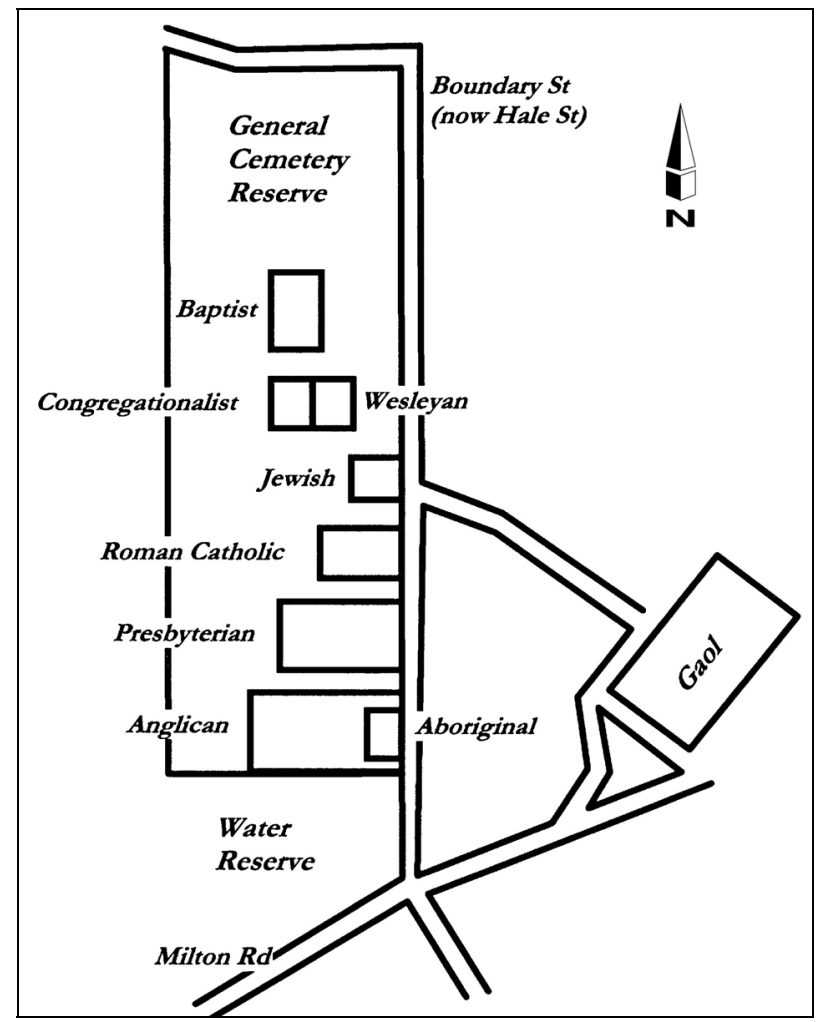

Figure 3. Location of burial grounds (after DNR CS7 1860 and DNR 1861).

Aborigines (QGG 1862 3(67), 1864 5(27):219, 1864 5(56):426, 1867 8(60):319; QPP 1914 (2):407). An acre each was apportioned to the Anglicans (Episcopalian), Roman Catholics and Presbyterians, while half acre lots were given to Independents (Congregationalists), Jews, Wesleyans and Aborigines (Fisher 1994:37).
By 1861 the Anglican cemetery had expanded to four acres and absorbed the Aboriginal burial area, the latter becoming redundant because of the diminishing number of Aboriginal people within the Brisbane area (Fisher 1994:38). The Presbyterians had also enlarged their reserve and the Baptists had acquired a parcel of land to the north of the Congregationalist/Wesleyan reserves (Fisher 1994:38). The Primitive Methodists applied for a site but failed to secure one.

During the 1850s and 1860s, Brisbane witnessed a rapid and unanticipated increase in population and urban development, and the cemeteries were soon bordered by streets and allotments (Brisbane Courier 15 March 1864). The cemeteries themselves became overcrowded with gravesites and fell into neglect. Ad hoc, shallow, or waterlogged burials were reported and the entire site posed a health risk due to its flood-prone hollows and proximity to the Milton water reserve (Brisbane Courier 15 March 1864; Fisher 1994:41). Considerable public pressure mounted to regulate burial procedures and establish a larger general cemetery at a site further from the town centre (Brisbane Courier 30 December 1862:2, 6 February 1864; Fisher 1994:37-38, 41).

In 1865 a Cemetery Act was passed by the Queensland Parliament that permitted the closure of the North Brisbane Burial Grounds (Fisher 1994:38, 41). By the 1870s new cemeteries controlled by the municipal council were established at other locations in the greater Brisbane region (Fisher 1994:36). However, because of ease of access, familiarity and lower burial costs, the North Brisbane Burial Grounds continued to be used as a place of interment by Brisbane residents until it was officially closed on 1 August 1875, although there is mention of sporadic burials occurring through to the 1890s (Fisher 1994:44; Hayman 1994:67). 


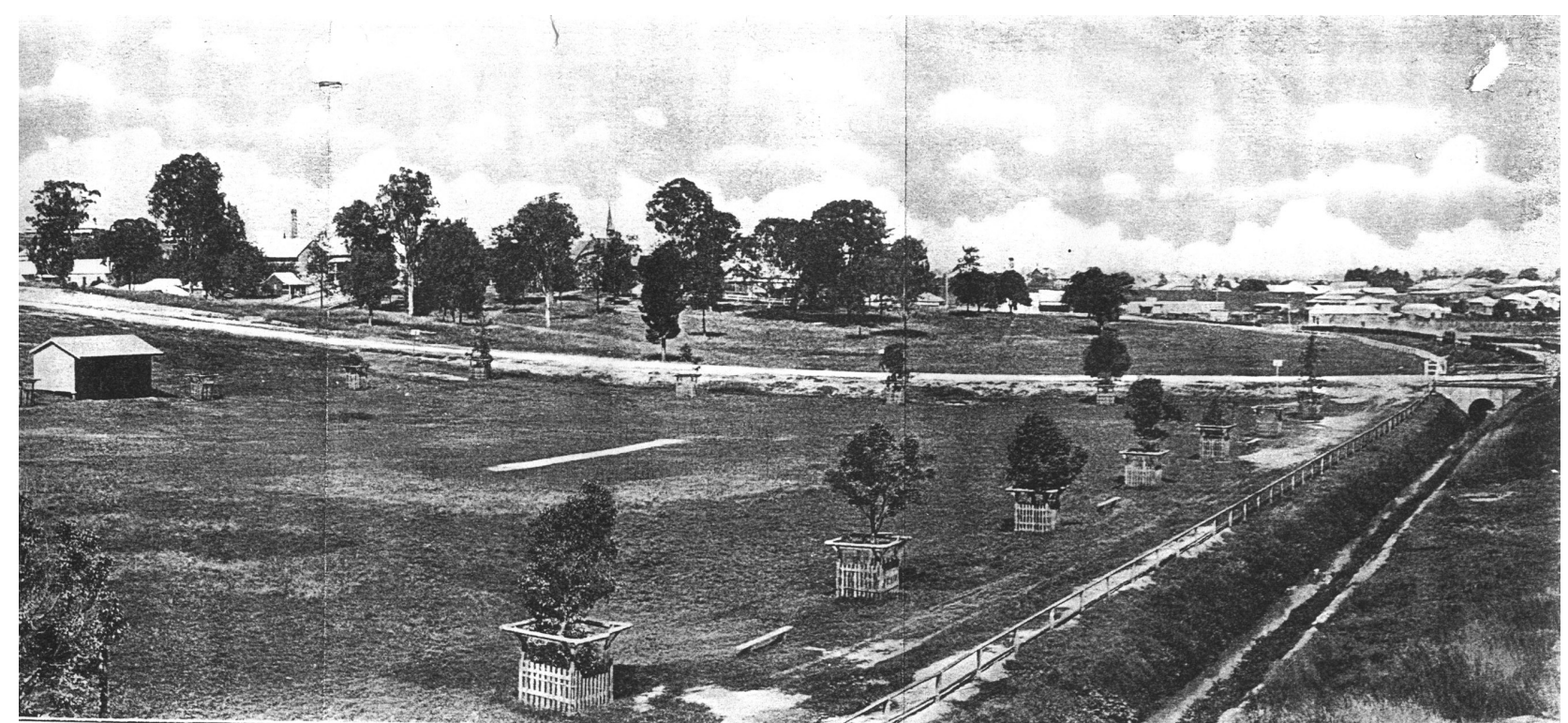

Figure 4. Lang Park with Milton Drain and landscaping (QPP 1914 (2):407).

Between the 1870s and 1890s, physical changes to the Burial Grounds occurred. Between 1875 and 1877, 40 to 50 bodies were exhumed as a result of the closure (Fisher 1994:52). Three streets (Judge, Caroline and Caxton) came to dissect the site from east to west (Fisher 1994:44, 1995:111). Caxton Street ran across part of the Jewish section, necessitating the complete removal or re-situating of some remains (Fisher 1994:52). Residential development and a new Petrie Terrace Boys School (built in 1888) encroached upon the Burial Grounds from the north while blocks of land immediately adjacent to the cemeteries were given over for government and recreational use (Fisher 1994:46, 1995:112; The Telegraph 11 October 1962:25).

In 1886 the open brick Milton Drain was dug along the western boundary to help drain the swamp (Figure 4) (The Builder and Contractor's News 15 July 1887:156). This structure was designed by William David Nisbet and J.B. Stanley. Nisbet was the Engineer in Charge of the City Drainage and he is credited with the design of much of the drainage of the inner city area (Richard 1980:4-7).

Despite these various alterations to the site, all the reserves except the Jewish cemetery survived reasonably intact through to the end of the nineteenth century. Over time, though, the problems of vandalism and neglect manifested themselves (Fisher 1994:46; QSA PRV 9892/1 4 June 1913, 28 July 1914) and the site became the focus of more public debate (Fisher 1994:46). Formal graveyards were now viewed as obsolete and ugly, while reformist movements in civic planning highlighted the need for open parkland in the densely inhabited working-class suburbs that the area now supported (Brisbane Courier 3 May 1975:8; Fisher 1995:129). Despite the construction of the Milton Drain, there were also sanitation problems posed by stagnant pools persisting within the disused graveyards.

A change of use from burial ground to recreation grounds was mooted in 1910 (Fisher 1994:47; QSA PRV 9892/1 28 July 1914). Approval for the conversion came with the passing in 1911 of the Paddington Cemeteries Act and the cancellation of all previous denominational grants (Fisher 1994:47). The conversion of the old cemeteries to a park was supervised by the Lands Department (QPP 1914 (2):407). The public was notified of the proposal for the establishment of a 'people's park', and a period of one year was given for concerned relatives to apply for the remains and/or memorials of deceased family members to be transferred to other cemeteries (Fisher 1994:47; QSA PRV $9892 / 128$ July 1914). The cost of exhumation and re-burial was defrayed by the Department.

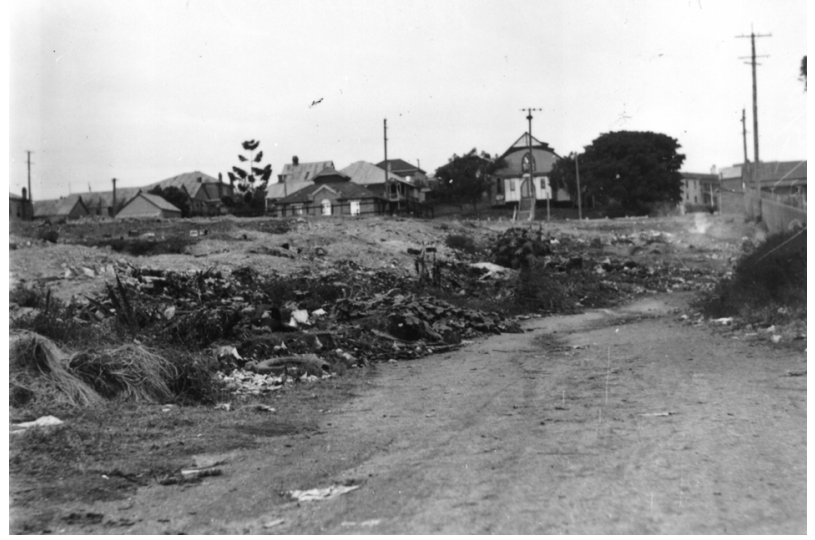

Figure 5. Landfill overlying the Roman Catholic section in the 1930s (JOL neg. 106336).

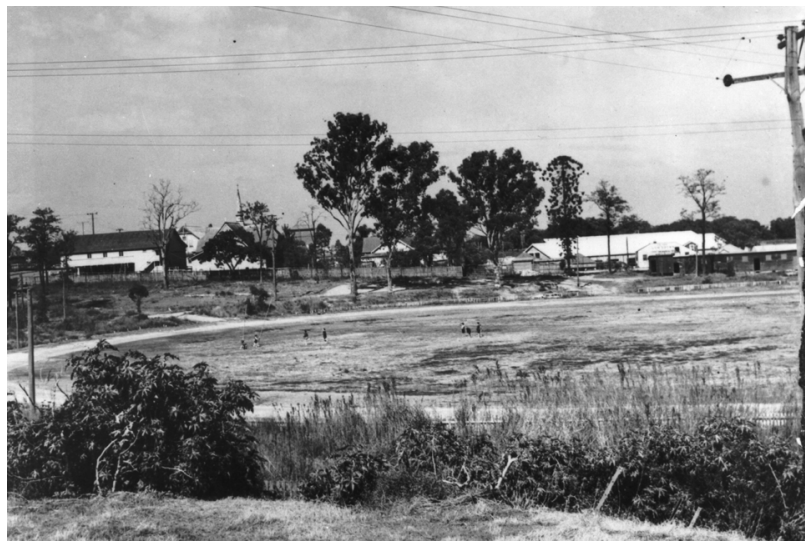

Figure 6. Lang Park athletics oval in the 1940s (JOL neg. 67706). 


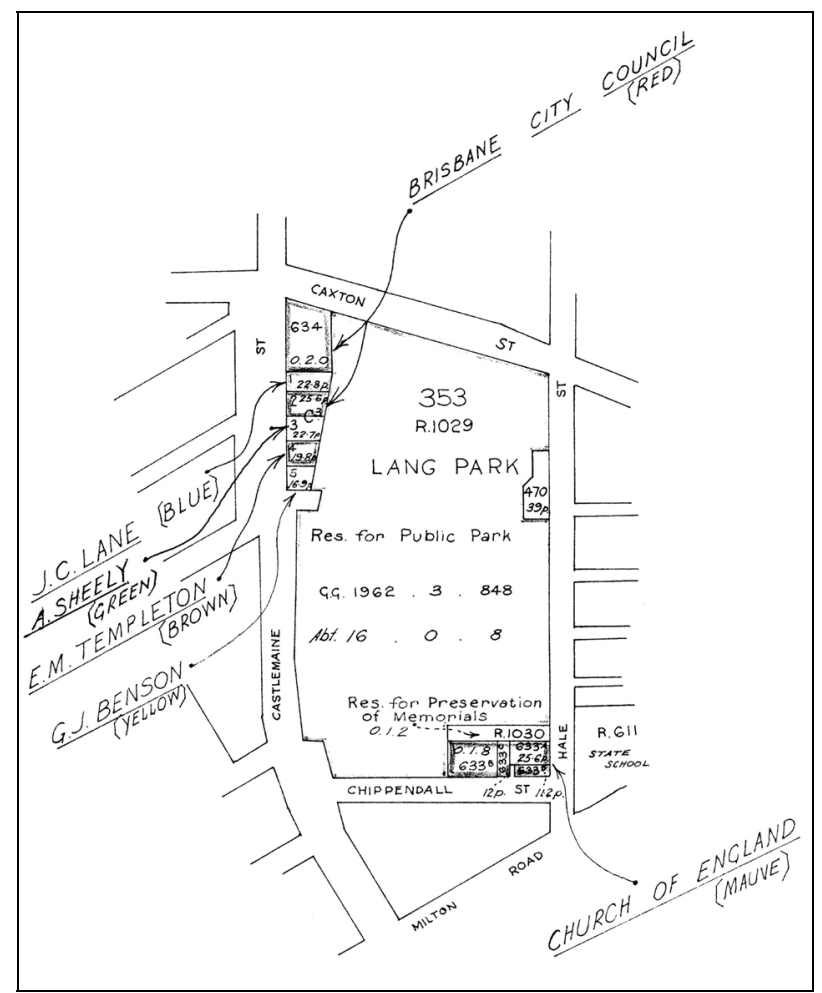

Figure 7. Plan of Lang Park (DNR Res. 915 n.d.).

Unfortunately locating graves proved difficult as no cemetery records could be found (QPP 1914 (2):407). Many graves were unmarked or had lost headstones, and it appears that in some cases bodies were buried secretly or unofficially (Fisher 1994:40; QPP 1914 (2):407; Hayman 1994:67). Furthermore, direct associations between the living and many of the dead had been lost through time, leading to faulty memories of gravesites or lack of response to the Lands Department advertisements (QPP 1914 (2):408).

Ninety-nine remains and 148 memorials were relocated, and 505 unclaimed memorials were stacked in a special memorial reserve, or 'buffer zone' along the northern side of the Anglican Christ Church (Fisher 1994:47; QSA PRV 9892/1 21 April 1914). In all approximately 150 graves were exhumed following the closure of the cemeteries in 1875. This number stands in marked contrast to the 4,643 graves that officers of the Lands Department located in 1914 (QPP 1914 (2):407) and Fisher's (1994:52) estimate that there were at least 10,000 interments in the North Brisbane Burial Grounds between 1843 and 1875.

Following the exhumations, the site was cleaned and leveled (QSA PRV 9892/1 12 June 1913, 9 July 1913, 25 July 1913, 3 October 1913, 6 November 1913, 31 March 1914, 16 April 1914). Repairs to the Milton Drain and its branches were undertaken (QSA PRV 9892/1 4 June 1913) and Judge Street was converted into a pedestrian access way. By mid-1914 most work was complete. The northern part of the Baptist cemetery was converted into the Paddington Kindergarten and Creche (QGG 1914102 (18):286; QSA PRV 9892/1 21 April 1914). The rest of the Baptist ground, plus the Congregational and Wesleyan cemeteries, and part of Caroline Street became the Ithaca Children's Playground (QGG 1914 102(145):1541; QSA PRV 9892/1 21 April 1914) (Figure 2). The bulk of the land south of Caxton Street, which included the Anglican,
Presbyterian, Roman Catholic and Jewish sections, was turned into a public park (QGG 1914 102(145):1541) (Figure 7). This constituted an area of 15 acres 1 rood 34 perches (50 hectares) and was duly named Lang Park in memory of the early Queensland pioneer, Dr John Dunmore Lang (QPP 1914 (2):409; QSA PRV 9892/1 21 April 1914). Christ Church and the memorial reserve in the southeast corner, and the land containing the Milton Drain were excluded from the park zone (QGG 1914102 (145):1541; QSA SRS 1748/1 no date; PRV 9892/1 4 June 1913; PRV 9892/1 21 April 1914).

After some initial wrangling, control of the new park went to the Ithaca Town Council, which initiated a program of shade tree planting and filling remaining hollows with garbage as well as silt from the Milton Drain (BCC Plan Custodian WDP 115 1928/1932; DNR Res. 915 10 May 1934; Fisher 1995:115; The Telegraph April 17 1914). It was not until 1924, when control of Lang Park was transferred to the Brisbane City Council, that the site began to be developed more intensely. During the 1920s and 1930s various improvements occurred, including the establishment of tennis courts at the northern and southern ends and the conversion of the Milton Drain into a closed system (BCC Plan Custodian WD B-7-29 1928; WDP 114 1928; WDP 115 1928/1932; Fisher 1995:117). However, the impetus for producing a recreational facility for the local population gradually faded. Throughout the rest of the twentieth century Lang Park gradually became fragmented and alienated from the general public by commercial, sporting and other interests.

Lang Park's use as a convenient garbage dump assumed a dominant role through to the 1950s, with the disposal of rubbish and nightsoil extending over large areas (DNR Res. 9158 May 1948, 27 August 1951; Fisher 1995:121-122; JOL c.1930 neg. 106336; QSA PRV 10121/1 31 December 1930) (Figure 5). In 1932, the Queensland Amateur Athletics Association (QAAA) obtained a lease over the southern portion of the park and by 1933 a fenced sporting ground was established, which included an oval with running track and associated facilities (Fisher 1995:117; DNR Res. 91528 May 1937, 14 May 1948, 26 October 1949, 10 November 1949) (Figure 6). In the 1920s the northern section saw a sewage maintenance depot built, followed by a BCC electricity substation, and then, during World War II the establishment of a military base (Brisbane Courier 6 September 1928; DNR Res. 9159 March 1942, 8 May 1948, 10 November 1949; Fisher 1995:121-122; Hayman 1994:79; Sun Magazine 7 May 1989:47). After the cessation of hostilities this area was leased to the Housing Commission and the Queensland Police-Citizens Youth Welfare Association (DNR Res. 91510 March 1955; Fisher 1995:122).

During the 1950s a struggle developed between various bodies over the control, financing and future direction of the park (Fisher 1995:122-123; DNR Res. 9157 August 1951, 16 February 1953). Between 1954 and 1959, the QAAA surrendered control of its area to Queensland Rugby League (QRL) and Brisbane Rugby League (BRL), which were lobbying to use the site as a new home for their code (Fisher 1995:122, 124-125; DNR Res. 91530 September 1955). The advent of the QRL/BRL tenancy, later to give rise to a special controlling body, the Lang 
Park Trust, marked the period of greatest development and change for the park (Fisher 1995:124-125). The old oval was upgraded and became enclosed to the north, east and south by terraced earth mounds with reinforced concrete risers (DNR Res. 91516 May 1957; Fisher 1995:125) (Figure 9). The other main physical changes were the removal of the old military buildings leased to the Housing Commission, and the construction of two large grandstands, one on the western side of the oval and one on the eastern (DNR Res. 91516 May 1957, 8 July 1957, 6 October 1978; Fisher 1995:125, 127).

During the 1980s and 1990s further changes occurred to the place. During the 1980s, the Queensland PoliceCitizens Youth Welfare Association (now Police Citizens Youth Club - PCYC) replaced its original facilities with a newer structure, and an indoor cricket complex was established, later to become the Ozsports Centre and beach volleyball courts (DNR Res. 91529 November 1984, 11 May 1994, 27 February 1997). In 1992, the controversial Hale Street ring-road was built which resulted in the resumption and excavation of a significant area of land along the eastern boundary of the park. This necessitated the demolition of a hall associated with the heritage-listed Christ Church, and the destruction of part of the memorial reserve (Fisher 1995:128; Hayman 1994; QGG 1989 91:1799). In 1993-1994 another major alteration to the site occurred with the replacement of the western grandstand by a massive six storey structure (the Suncorp/Metway grandstand) capable of seating 13,000 (Fisher 1995:128). Finally, in the mid-1990s, in the northwest corner of the park, the Queensland Government Sporthouse building was constructed.

\section{Assessment of Archaeological Potential}

UQASU's approach to the assessment of the potential subsurface archaeological material at the Lang Park redevelopment site closely followed the approach advocated by Pearson and Sullivan (1995). This approach emphasises the division of the process of cultural heritage management planning into three sequential stages: significance assessment; management policy; and development of management strategies.

\section{Significance Assessment}

The Burra Charter (Marquis-Kyle and Walker 1992:21) defines cultural significance as 'aesthetic, historic, scientific or social value for past, present or future generations'. This is mirrored by the Queensland Heritage Act, 1992 that defines cultural heritage significance under Section 4 of the Act as 'aesthetic, historic, scientific or social significance, or other special value, to the present community and future generations'. Two important factors that impact on the significance of a cemetery and its contents are rarity and integrity (New South Wales Heritage Office 1998:7). It may not be possible to disentangle these different elements of significance as the community's understanding of a place is usually built on many intertwined elements. Nonetheless, it is the cultural significance of a place that should determine how its cultural heritage is managed.

Information concerning the various 'values' of Lang Park, and how these might have been impacted upon by the material changes that have occurred over time at the site, came from a number of sources. Historical information was collected from Queensland State Archives, Brisbane City Council, John Oxley Library, University of Queensland Applied History Centre, Department of Natural Resources, and Lang Park Trust. Interviews were conducted with people who have been, or currently are, responsible for management of the area. Information on social significance was obtained from a number of representatives of the major church groups and from newspaper articles concerning previous disturbance to the site. Physical evidence for levels of fill and other material changes was gathered by a site inspection and the results of borehole and testpits dug by Sinclair Knight Merz Pty Ltd and ARUP Geotechnics for the purpose of testing for contaminated soils. From the assessment of the gathered data, a number of 'Statements of Significance' were generated concerning three historical elements of Lang Park: the cemeteries; the Milton Drain; and the old landfill.

\section{The Cemeteries}

The cemeteries have high historic and scientific value. Because they were the principal places of interment in Brisbane for the first 30 years after free settlement commenced, they are unique. The cemeteries can not only provide data on early cemetery design, civic planning and sanitation, but they are intimately linked to the political, social and demographic processes of an important formative period for Paddington, Brisbane and Queensland more generally.

A key factor in determining the significance of the cemeteries was their integrity. Long-standing official attitudes towards the cemeteries have maintained that nothing could be left of them due to past exhumations and various phases of building work on the site (e.g. Malone and Koch 2001). Yet from the historic information alone there was sufficient evidence to suggest that a large number of graves remained undisturbed beneath the current land surface. Since 1914 the site has been steadily covered by a protective layer of fill. Although some cutting has occurred, prior to the 1970s excavations for building footings and other structures it remained relatively unintrusive. It was only with the construction of the eastern grandstand and the Hale Street ring-road that any significant portions of the cemeteries were destroyed. The remaining burials and their contents therefore have potential to provide information on the conditions of life within the colony, including health (e.g. Higgins 1989), mortality rates, nutrition (e.g. Sullivan et al. 1989), religious and socio-cultural practices (e.g. Little et al. 1992), gender, status and class.

The cemeteries also have social significance. Many early pioneers, both prominent and humble, were buried at Lang Park (QPP 1914 (2):408). Consequently there remain people today who wish to preserve the memory and the resting places of these pioneers, or are aware of family members who are interred there. A single level of social significance was difficult to establish, though, due to the variety of opinions and attitudes within the local community and religious groups consulted. However, during the Hale Street widening in the 1990s, it was clear that much distress and ill-feeling was engendered by the destruction of graves (see Doughty 1991:1; Robertson 1991). 


\section{The Milton Drain}

The Milton Drain has high historic and scientific significance. Historic sources indicate that the original brickwork survived the installation of concrete piping within it and now lies buried beneath fill and the foundations of the western grandstand. It exists as the last surviving example of this style of drain from the nineteenth century in Brisbane (B. Rough, Brisbane City Council, pers. comm., 2000). Not only is the drain associated with an important early engineer, William Nesbit, it has potential to yield architectural, town planning and engineering information. Any deposits retained inside the drain may provide data on early diet, environment, health and nutrition.

\section{The Historic Landfill}

The rubbish dumped on the site has low historic and moderate scientific significance. The results from test pitting and boreholes conducted as part of the construction process indicated a layered deposit of ash, fill, ceramics, metal, glass and organic matter across most of the site. The depth of this deposit varied from less than $1 \mathrm{~m}$ in the south to over $7 \mathrm{~m}$ in the north (Sinclair Knight Merz Pty Ltd 2000). Although it would appear that an extensive and reasonably sound archaeological deposit exists that has potential to yield data on twentieth century material culture, consumption patterns and landfill formation processes in Brisbane, there are many other local sites that can provide similar information.

\section{Management Policy and Development of Management Strategies}

From the 'Statements of Significance', three Zones of Cultural Heritage Significance were generated. These zones were High Significance (the cemeteries and the Milton Drain), Low-Medium Significance (the landfill) and No Significance (those areas disturbed to a large extent by previous building activity).

Two Impact Zones (High and Low) were also established which detailed the level of intrusion upon the archaeological record by the redevelopment. The new stadium complex encompasses almost the entire site and requires the demolition of the earth mounds, eastern grandstand and the Ozsports/Police Citizens Youth Club facilities. However, due to the types of footings to be used and the varied levels of fill in different areas its impact is not uniform. In some areas its effects are negligible while in the Zone of High Impact it is impossible to preserve any subsurface material.

From the onset of the cultural heritage assessment, UQASU was informed that the redevelopment would and had to proceed no matter the outcome of the assessment. Our task was to manage the impact on the cultural remains within the redevelopment's given time frame. After a review of the goals of the heritage management and redevelopment aspects at Lang Park, conflicts were identified and a Cultural Heritage Management Policy was developed accordingly. This policy called for the in situ conservation of elements of high significance where possible. The entirety of the Milton Drain and certain sections of the cemeteries could be retained because they lay within the Zone of Low Impact. The sections of the cemeteries in the Zone of High Impact could not be preserved and would need to be archaeologically salvaged and investigated prior to appropriate re-interment of any remains recovered. At various points across the site archaeological sampling of the landfill would also be required.

In order to implement the recommended Management Policy, Cultural Heritage Management Areas were generated through the intersection of the Zones of Cultural Heritage Significance and the Zones of Impact (Figure 8). Area 1 was where the redevelopment would have high impact upon an element of high cultural significance. As Figure 8 shows, this encompasses sections of the Anglican, Aboriginal, Presbyterian and Roman Catholic cemeteries. Area 2 was all other parts of the redevelopment, including the Milton Drain, which would not be impacted upon.

Sets of Management Strategies, tied to the different phases of the redevelopment, were devised for each of these zones. Applying to all stages and areas of the redevelopment was the requirement that work must comply with provisions of the Queensland Heritage Act, 1992 and the Cultural Record (Landscapes Queensland and Queensland Estate) Act, 1987. Consequently it was recommended that a program of cultural awareness training be initiated as part of the general workplace induction so that demolition and construction personnel could be made aware of their legal obligations and also how their activities may impact on the archaeological record.

In Cultural Heritage Management Area 1, it was recommended that due care be taken during demolition and that an archaeological consultant periodically monitor progress. It was also recommended that access routes for vehicles be designed to minimise disturbance to the ground surface and that security precautions be implemented to ensure that amateur collectors and others did not destroy the archaeological context once the demolition exposed subsurface sediments.

After demolition but prior to the construction phase, a major archaeological salvage program of the remaining burials was to be undertaken in Cultural Heritage Management Area 1. This would involve the excavation, mapping and laboratory analysis of burials and contents by suitably qualified archaeologists. In the Aboriginal section, this process would occur with Indigenous involvement. All artefacts removed during the excavations needed to be conserved and curated according to the requirements of the Queensland Museum or, in the case of Aboriginal material, treated in accordance with the wishes of the traditional owners.

Prior to the start of the excavation and analysis, arrangements were made with the Brisbane City Council for the re-interment of any non-Indigenous skeletal material removed from the site. Should skeletal or burial material be unearthed during the construction process a suitably qualified archaeological consultant and the Cultural Heritage Branch of the Environmental Protection Agency would have to be notified at once and the salvage procedures implemented.

In Cultural Heritage Management Area 2, a sondage sampling strategy across the redevelopment site was recommended to ensure that a representative sample of artefacts from the twentieth century dumping phase of the site was collected. These artefacts would need to be conserved and deposited with the Queensland Museum. 
Table 1. Number of graves excavated from each section and estimated total number of burials.

\begin{tabular}{|c|c|c|c|c|c|c|c|}
\hline Section & $\begin{array}{c}\text { Total } \\
\text { Area } \\
\left(\mathbf{m}^{2}\right)\end{array}$ & $\begin{array}{c}\text { Excavated } \\
\text { Area } \\
\left(\mathbf{m}^{\mathbf{2}}\right)\end{array}$ & $\begin{array}{l}\% \text { Total } \\
\text { Area } \\
\text { Excavated }\end{array}$ & $\begin{array}{l}\text { \# Burials } \\
\text { Identified }\end{array}$ & $\begin{array}{l}\text { \# Burials } \\
\text { Removed }\end{array}$ & $\begin{array}{l}\text { Density of Burials } \\
\quad\left(\text { per } 100 \mathrm{~m}^{2}\right)\end{array}$ & $\begin{array}{c}\text { Estimated } \\
\text { Total } \\
\text { Burials }\end{array}$ \\
\hline Anglican/Aboriginal & 16200 & 2450 & 15.1 & 335 & 199 & 13.67 & 2215 \\
\hline Roman Catholic & 4050 & 1150 & 28.4 & 219 & 163 & 19.04 & 771 \\
\hline Presbyterian & 6070 & 550 & 9.1 & 37 & 35 & 6.73 & 408 \\
\hline
\end{tabular}

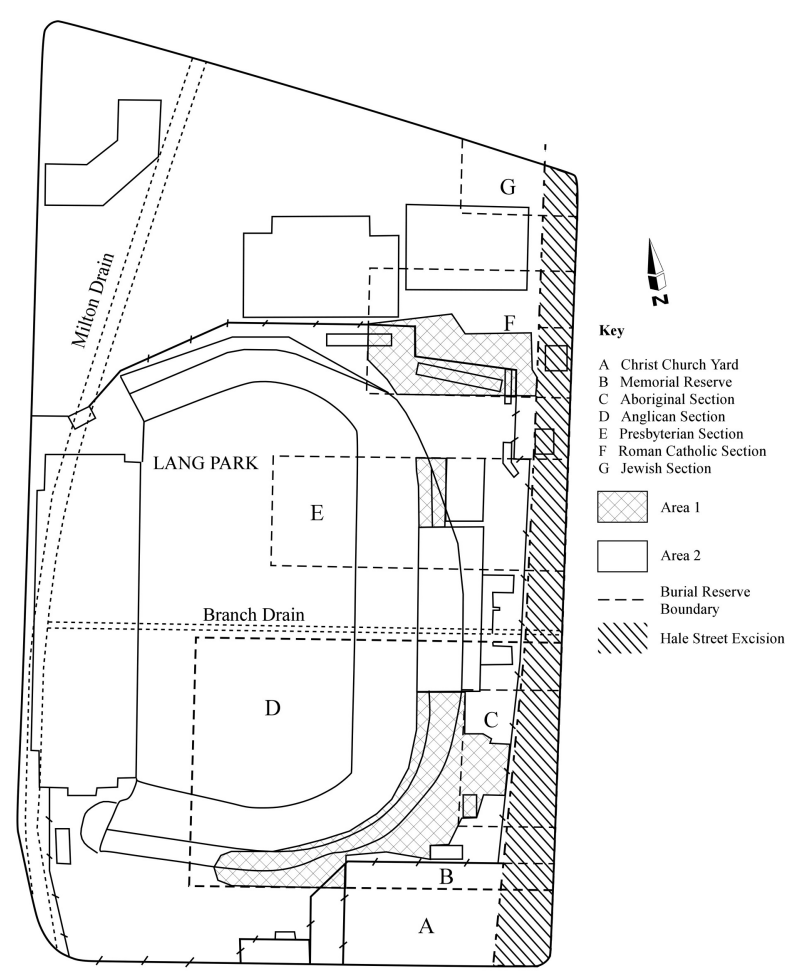

Figure 8. Cultural Heritage Management Areas.

Care also needed to be taken during the removal of two large fig trees growing on the site. One was situated in the vicinity of the Milton Drain on the northern side of the Suncorp/Metway grandstand and in this case the removal could impact on the brickwork of the drain. The second tree was located within the area of the Aboriginal cemetery and its removal had the potential to disturb gravesites.

Following the construction of the new stadium UQASU recommended that a memorial be erected to inform the visiting public of the importance of the site as the location of the first cemeteries related to the free settlement of Brisbane. Furthermore, any new developments proposed in any part of the Zone of High Cultural Heritage Significance would require the implementation of mitigation and salvage strategies.

\section{Implementation of the Cultural Heritage Management Policy and Strategies}

In August 2001 demolition of the eastern stand, terraced concrete seating, earth mounds and associated buildings at Lang Park commenced. Prior to this considerable consultation between the developers (the Lang Park Joint Venture), Project Services, UQASU, the Turrbal Association Inc., church groups, including the Brisbane Council of Churches and the Chevra Kadisha (Jewish
Burial Society), and subcontractors occurred. There were many issues to consider, including the safe removal of contaminated fill, the control of media coverage, compliance with workplace health and safety regulations, and the development of site protocols for scientific staff, demolition and construction employees and visitors. There were issues not always associated with an archaeological project, such as dealing with the politics and the legal demands of the construction industry, and the heightened public emotions attached to these cemeteries and the human remains that they contained. With regard to the latter, concern over the disturbance of gravesites was acknowledged through an on-site ecumenical service held by church leaders and plans for a re-interment ceremony.

As in any project of this scale, it has been necessary for all parties to learn and accommodate the goals and methods of the others. A cultural heritage procedures manual was developed which formed the basis for the cultural heritage awareness training of demolition/construction crews. Conversely, archaeological personnel have been required to undergo general and site-specific safety inductions and to comply with general construction site practices.

In August, 2001, UQASU began the salvage of the affected cemetery areas, initially in the Aboriginal section (in Cultural Heritage Management Area 1) with Turrbal representatives assisting with the excavation, and then moving out into the Anglican area. Later salvages of the Roman Catholic and Presbyterian sections also occurred whilst no archaeological activities were carried out in the Jewish, Baptist, Congregationalist or Wesleyan areas. Our methods have been to use large excavators (20 tonne) with batter buckets to remove layers of twentieth century landfill until the original 1914 land surface is revealed (Figure 10). This was then assessed for changes in soil colour and texture indicating grave locations (see Owsley et al. 1997:210, Plate 12.6). Rectangular gravesite soil 'stains' stood out clearly from the undisturbed ground surface (Figures 10 and 11). These were identified and mapped. As this was a salvage operation with time being a priority, the heavy excavation machinery was retained to scrape back the subsoil until either burial remains such as coffin outlines or wood were exposed or the pad level for the new stadium's footings reached. Those gravesites which contained recognisable material were assigned feature numbers and their details recorded and photographed. These were then removed using standard archaeological techniques. Samples of coffin wood, coffin furniture and burial sediments were retained for laboratory analysis (Figure 12). Possible remains of demolished tombs, including terracotta edging, shells, and dressed sandstone and porphyry, were collected and recorded. 


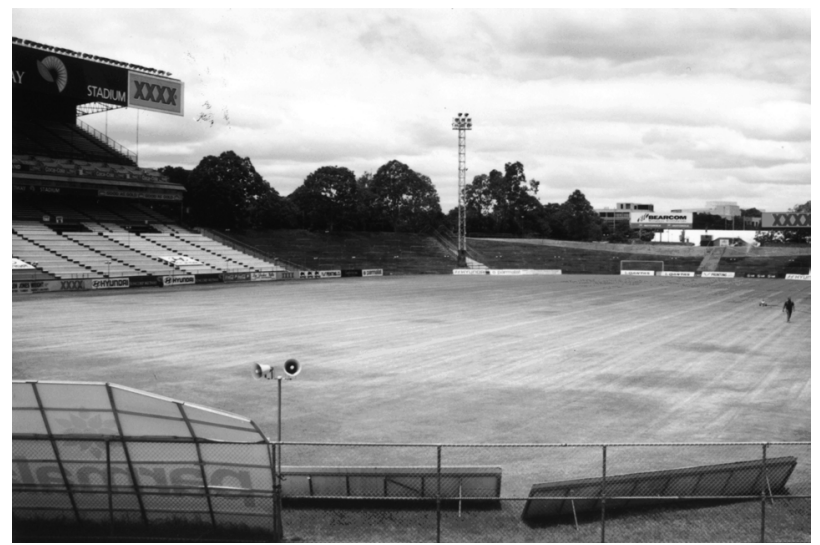

Figure 9. Lang Park playing field in 2000 (Photograph: UQASU).

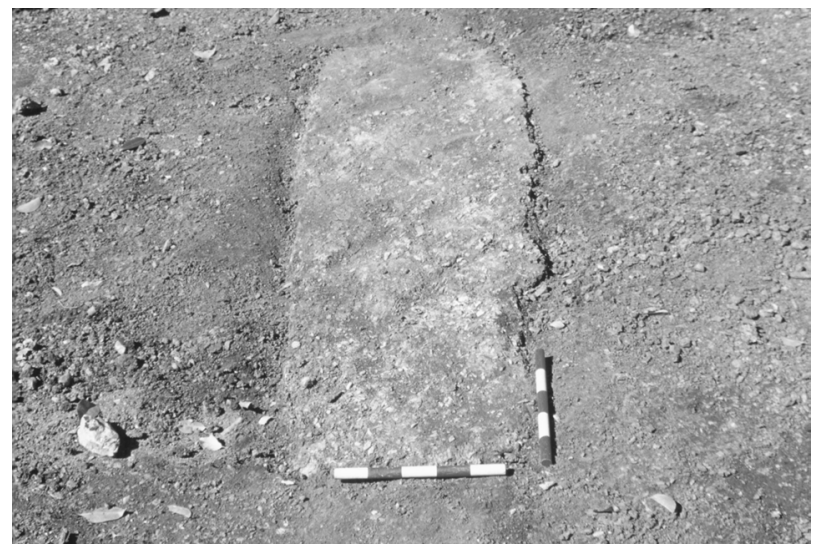

Figure 11. Grave 'stain' in Anglican section (Photograph: UQASU).

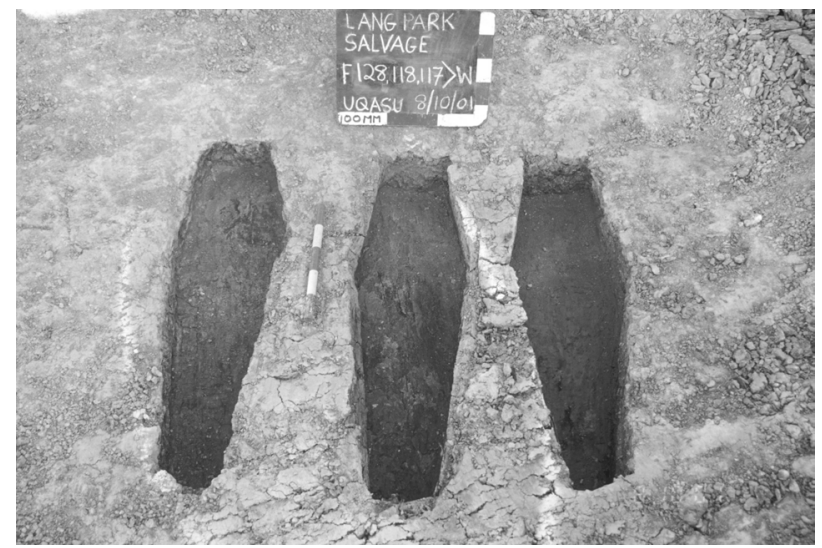

Figure 13. Three burials in Roman Catholic section (Photograph: UQASU).

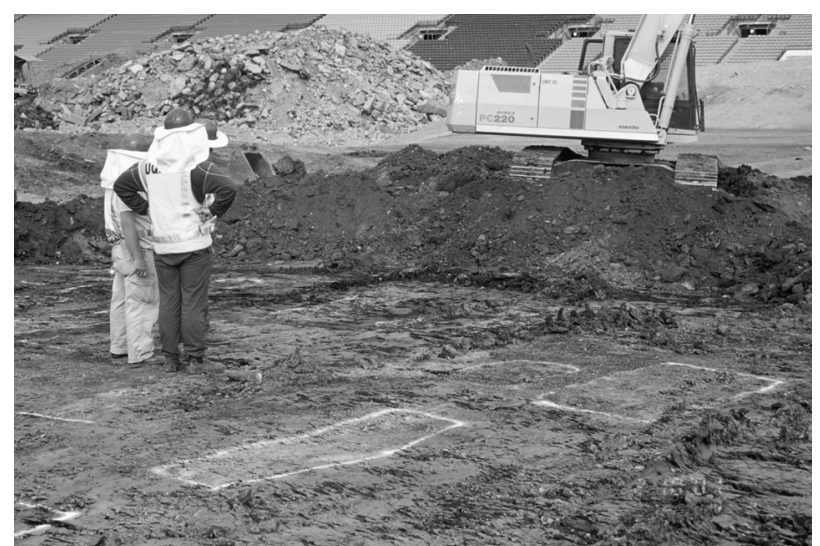

Figure 10. Excavator exposing gravesites in the original land surface (Photograph: UQASU).

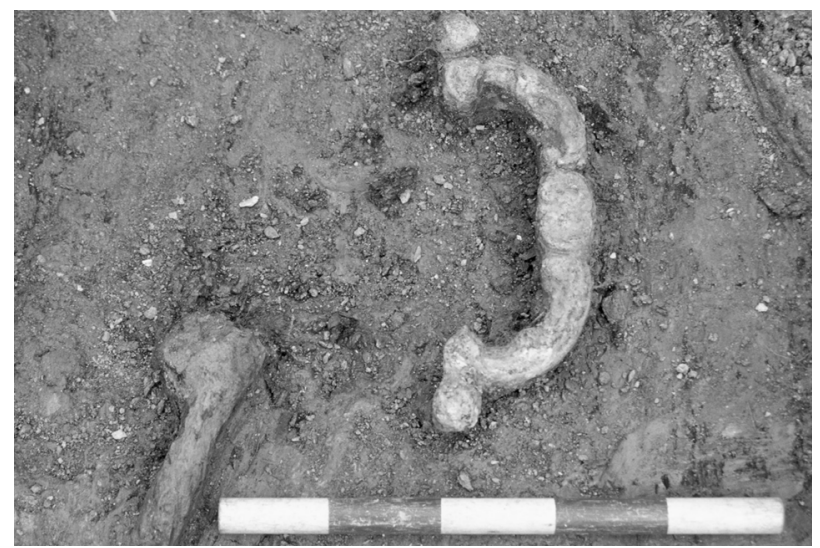

Figure 12. Coffin handles from a grave in the Presbyterian section (Photograph: UQASU).

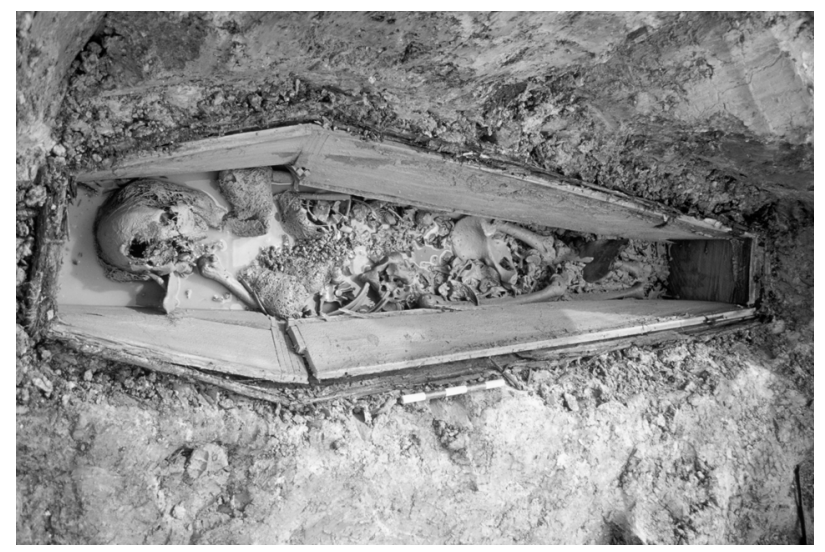

Figure 14. Complete coffin and contents removed from the Roman Catholic section (Photograph: UQASU). 


\section{Preliminary Results}

Our prediction that a large number of burials would have survived post-depositional and building activities on the site has proven to be correct. To date 397 burials have been exhumed along with a broken headstone and a trench containing broken monumental masonry. The headstone was collected from the Roman Catholic section and was marked simply 'JS 1874'. One hundred and eighty-three burials have been exhumed from the Anglican section, 16 from the Aboriginal section, 163 from the Roman Catholic section and 35 from the Presbyterian section (Table 1). The concentration of burials varies in each section with the Roman Catholic section containing more than triple the density of the Presbyterian section. Many of the burials in the Roman Catholic section were placed very close together indeed (Figure 13). From the results presented in Table 1 and using the density from the Presbyterian section as a guide to the maximum densities of the unexcavated sections we estimate that approximately 4,500-5,000 burials occurred in the North Brisbane Burial Grounds. This figure more closely corresponds to the 1914 Lands Department count of 4,643 marked graves made than Fisher's (1994:52) estimate of 10,000 burials. This disparity demonstrates the validity of an archaeological approach in the management of historic cultural heritage.

The majority of the excavated graves have proved to be relatively shallow, being dug into hard subsoils consisting of clay and phyllite fragments overlying a phyllite base. This may confirm historic reports of ad hoc burial practices at the site. Most remains have shown poor levels of preservation for organic material. In many cases, particularly with regard to children's graves, both bone and wood have become little more than dark stains in the subsoil. Three intact coffins have been disinterred (one from the Anglican section and two from the Roman Catholic section) and their contents will be removed under laboratory conditions (Figure 14). The excavation and analysis results will be published in detail separately.

\section{Conclusion}

The Lang Park site has had a long and varied history, which, since 1914, has entailed considerable physical change. The current redevelopment is just another chapter in that history. Its use has altered from a burial place, to a public park, and then to a commercial sporting ground. Many of the changes to the site have been the result of the need to solve drainage issues and fill in low-lying land and hence the nineteenth century land surface now lies beneath twentieth century fill. Various structures have also come and gone, and in some areas deep excavation has occurred.

Developing and applying an appropriate Cultural Heritage Management Policy to manage the impact of the redevelopment has proved a challenge. The site is large and complex in terms of the placement of present and past features and sediments, and there are also associated competing social, political, economic and scientific factors. While the salvage excavation is not yet complete, it promises to yield valuable insights into colonial life in Brisbane. Already it has demonstrated that many gravesites have been preserved. Furthermore, this is arguably the largest and one of the most important historical archaeological excavations in Queensland, and is a valuable test case for cultural heritage management, cemetery salvage methodology, and the structuring of relationships between archaeologists, traditional owners, community groups and developers.

\section{Acknowledgements}

We would like to thank Peter Teys, Steve Hobson, Al Wolski and Graeme Pierce from Project Services and Peter Zahnleiter and Liz Baker of Sinclair Knight Merz Pty Ltd for the financial and logistical support that enabled this project to proceed. We would also like to thank all those people who provided us with historical or social information including the Lang Park Trust, Rod Fisher (Department of History, University of Queensland), Bill Oliver (Queensland Institute of Engineers), Doug Ferguson (Department of Natural Resources), Bill Kitson (Department of Natural Resources), Pastor Owen Strong (Christ Church), Brian Rough (Brisbane City Council), Father Martin (Roman Catholic Centre) and Morris Orchert (Jewish Burial Society). We are particularly indebted to Ade Kukoyi and Maroochy Barambah from the Turrbal Association Inc. for their active involvement. We also thank all those who oiled the cogs of government machinery for us including Craig Wall and Catherine Westcott (Environmental Protection Agency), Richard Robins (Queensland Museum), and Tony Tilden (Brisbane City Cemeteries Administration). We thank the John Oxley Library and particularly Jane Meadows for permission to reproduce Figures 2, 5 and 6. Thanks also goes to the employees of the Lang Park Joint Venture who facilitated our stay on site including David Ghannoum, Jim Russ, Gordon Sutherland, Bruce McPherson, Bill Robinson and Mark Houston.

Finally we are indebted to Tam Smith for her unfailing professionalism and dedication in directing the salvage excavation work on the Lang Park site and to the excavation crew, namely Fran Ashton, Nicola Bristed, Tamara Brown, Angus Crawford, Alison Crowther, Cameo Dalley, Ken Dusza, Tony Eales, Joe Firinu, Victoria Francis, Michael Haslam, Paul Kajewski, Anthony McKeough, Cassandra Kelly, Andrew McLaren, Adrian Murphy, Annie Sallows, Belinda Taylor, Nathan Woolford and Paddy Waterson.

\section{Abbreviations}

\section{BCC Brisbane City Council}

DNR Department of Natural Resources

JOL John Oxley Library

QAAA Queensland Amateur Athletics Association

QGG Queensland Government Gazette

QPP Queensland Parliamentary Papers

QRL Queensland Rugby League

QSA Queensland State Archives

UQASU University of Queensland Archaeological Services Unit

\section{References Cited}

BCC Plan Custodian WD B-7-29 City of Brisbane Proposed Sewer through Lang Park Caxton St. to Milton Rd. Milton, 1928.

BCC Plan Custodian WDP 114 Works Detail Plan 1928.

BCC Plan Custodian WDP 115 Works Detail Plan 1928/1932.

Brisbane Courier.

Courier Mail.

DNR CS7, Plan of the Burial Grounds, Parish of North Brisbane, North Brisbane, County of Stanley, 1860. Housed at DNR Museum.

DNR Plan of Allotments Petrie Terrace, City of Brisbane, Parish of North Brisbane, County of Stanley, Queensland. For Surveyor-General's Office 1861

DNR Res. 915 Lang Park n.d.

DNR Res. 915 Memorandum of Agreement 10 May 1934.

DNR Res. 915 Lands Department Correspondence 28 May 1937. 
DNR Res. 915 Lands Department Correspondence 9 March 1942.

DNR Res. 915 Lands Department Correspondence 8 May 1948.

DNR Res. 915 QAAA Correspondence to Minister of Lands 14 May 1948.

DNR Res. 915 Lands Department Correspondence 26 October 1949.

DNR Res. 915 QAAA Correspondence to Premier and Minister of Lands, 10 November 1949.

DNR Res. 915 QRL Correspondence with Minister of Lands 7 August 1951.

DNR Res. 915 Lands Department Correspondence 27 August 1951.

DNR Res. 915 Lands Department Correspondence 10 March 1955.

DNR Res. 915 Lands Department Correspondence 30 September 1955.

DNR Res. 915 Lands Department Correspondence 16 May 1957.

DNR Res. 915 Lands Department Correspondence 8 July 1957.

DNR Res. 915 Lands Department Correspondence 6 October 1978.

DNR Res. 915 Lands Department Correspondence 29 November 1984.

DNR Res. 915 Lands Department Correspondence 11 May 1994.

DNR Res. 915 Lands Department Correspondence 27 February 1997.

Doughty, J. 1991 Row on secret coffin move. Courier Mail 2 January 1991 p.1.

Fisher, R. 1994 That controversial cemetery: The North Brisbane Burial Grounds 1843-75 and beyond. In R. Fisher and B. Shaw (eds), Brisbane: Cemeteries as Sources, pp.35-52. Brisbane: Brisbane History Group Inc.

Fisher, R. 1995 The spotlight on Lang Park: The recycled cemetery as a socio-political football. In R. Fisher and B. Shaw (eds), Brisbane: People, Places and Progress, pp.111131. Brisbane: Brisbane History Group Inc.

Hayman, N. 1994 Resumed in Protest: The Human Cost of Roads. Grays Point, NSW: Bungoona Books.

Higgins, V. 1989 A model for assessing health patterns from skeletal remains. In C.A. Roberts, F. Lee and J.L. Blintiff (eds), Burial Archaeology: Current Research, Methods and Developments, pp. 175-204. BAR British Series 211. Oxford: BAR.

HOK Sport and PDT Architects 2001 Brisbane Football Stadium at Lang Park: Developed Design. Unpublished report to the Queensland Government.

Little, B.J., K.M. Lanphear and D.W. Owsley 1992 Mortuary display and status in a nineteenth-century Anglo-American cemetery in Manassas, Virginia. American Antiquity 57(3):397-418.

Marquis-Kyle P. and M. Walker 1992 The Illustrated Burra Charter: Making Good Decisions About the Care of Important Places. Canberra: Australia ICOMOS Inc.

Malone, P. and T. Koch 2001 Stadium threat to graves. Courier Mail 5 July 2001 p. 1.

New South Wales Heritage Office 1998 Skeletal Remains: Guidelines for the Management of Human Skeletal Remains under the Heritage Act 1977. Sydney: New South Wales Heritage Office.

Owsley, D.W., B.B. Ellwood and M.L. Richardson 1997 Locating and excavating historic burials. In D.A. Poirier and N.F. Bellantoni (eds), In Remembrance: Archaeology and Death, pp.201-217. Westport, CT: Bergin and Garvey.
Pearson, M. and S. Sullivan 1995 Looking After Heritage Places: The Basics of Heritage Planning for Managers, Landowners and Administrators. Melbourne: Melbourne University Press.

Prangnell, J. and K. Rains 2001 Cultural Heritage Report of Historical Landscapes and Materials at the Lang Park Redevelopment Site. UQASU Report 344. Brisbane: University of Queensland Archaeological Services Unit.

Queensland Government Gazette.

QPP vol. 21914 Report Regarding the Operations Undertaken at the Paddington Cemeteries. pp.407-419.

QSA PRV 9892/1 4 Item 646 Works Carried out by the Public Estate Improvement Branch, June 1913.

QSA PRV 9892/1 Item 646 Works Carried out by the Public Estate Improvement Branch, 4 June 1913.

QSA PRV 9892/1 Item 646 Works Carried out by the Public Estate Improvement Branch, 12 June 1913.

QSA PRV 9892/1 Item 646 Works Carried out by the Public Estate Improvement Branch, 9 July 1913.

QSA PRV 9892/1 Item 646 Works Carried out by the Public Estate Improvement Branch, 25 July 1913.

QSA PRV 9892/1 Item 646 Works Carried out by the Public Estate Improvement Branch, 3 October 1913.

QSA PRV 9892/1 Item 646 Works Carried out by the Public Estate Improvement Branch, 6 November 1913.

QSA PRV 9892/1 Item 646 Works Carried out by the Public Estate Improvement Branch, 31 March 1914.

QSA PRV 9892/1 Item 646 Works Carried out by the Public Estate Improvement Branch, 16 April 1914.

QSA PRV 9892/1 Item 646 Works Carried out by the Public Estate Improvement Branch, 21 April 1914.

QSA PRV 9892/1 Item 646 Works Carried out by the Public Estate Improvement Branch, 28 July 1914.

QSA PRV 10121/1 Item 2 Reports Regarding Dams, Water Supply etc. 1922-1940, 31 December 1930.

QSA SRS 1748/1 Item 152 Paddington Cemeteries: Plans Showing the Old Paddington Cemeteries and the Present Reserves, n.d.

Richard, E.L. 1980 Early Brisbane stormwater drainage to 1887. Queensland Technical Papers 21(14):1-7.

Robertson, B. 1991 Old photo may pin down gravesites. Courier Mail 12 January 1991.

Sinclair Knight Merz Pty Ltd 2000 Lang Park Redevelopment Stage 1 Contaminated Site Assessment Location Plan.

Sullivan, E.O., S. Williams and M.E.J. Curzon 1989 Dental caries and nutritional stress in English archaeological child populations. In C.A. Roberts, F. Lee and J.L. Blintiff (eds), Burial Archaeology: Current Research, Methods and Developments, pp.167-174. BAR British Series 211. Oxford: BAR.

Sun Magazine.

The Builder and Contractor's News.

The Telegraph.

Turrbal Association Inc. 2001 Turrbal Cultural Heritage Report (Indigenous Historical and Cultural Analysis) for the Proposed Lang Park Redevelopment. Unpublished report to Sinclair Knight Merz Pty Ltd.

Turrbal Association Inc. and UQASU 2001 Summary Cultural Heritage Management Plan for the Proposed Lang Park Redevelopment. Unpublished report to Sinclair Knight Merz Pty Ltd. 